\title{
Rainfall, temperature, and vegetation type influence nesting by the oil-collecting bee Centris (Hemisiella) tarsata in Brazilian restinga
}

\author{
Danúbia Maria da Costa ${ }^{1,2}$, Michela Costa BAtista ${ }^{3}$, Amaury Soares de Brito ${ }^{2,4}$, \\ Inácio de BARros ${ }^{5}$, Adenir Vieira TEODORO ${ }^{1,2}$ \\ ${ }^{1}$ Programa de Pós-Graduação em Agroecologia, Universidade Estadual do Maranhão, Travessa Paulo VI, s/n-Cidade \\ Universitária Paulo VI, São Luís, MA 65057-630, Brazil \\ ${ }^{2}$ Embrapa Tabuleiros Costeiros, Av. Beira-Mar 3250, Jardins, Caixa Postal 44, Aracaju, SE, Brazil \\ ${ }^{3}$ Programa de Pós-Graduação em Agricultura e Ambiente, Universidade Estadual do Maranhão, Centro de Estudos \\ Superiores de Balsas, Praça Gonçalves Dias s/n Centro, Balsas, MA 65800-000, Brazil \\ ${ }^{4}$ Programa de Pós-Graduação em Agricultura e Biodiversidade, Universidade Federal de Sergipe, Av. Marechal Rondon, \\ s/n-Jd. Rosa Elze, São Cristóvão, SE, Brazil \\ ${ }^{5}$ Embrapa Gado de Leite, Rua Eugênio do Nascimeno, 610-Dom Bosco, 36038-330, Juiz de Fora, MG, Brazil
}

Received 2 February 2019 - Revised 22 July 2019 - Accepted 5 September 2019

\begin{abstract}
Solitary bees are the main pollinators of native plant species and crops, therefore, understanding how they respond to the environment is essential to maintain ecosystem function and services. Here, we assessed how climatic conditions and vegetation type influence Centris tarsata nesting in Brazilian restinga. Evaluations were conducted using trap-nests placed in open areas, shrubby and secondary vegetations, and at understory and canopy in open areas and secondary vegetations. Overall, nesting was higher during the dry season, mostly in open areas at a height of $1.5 \mathrm{~m}$. However, in shrubby and secondary vegetations, nesting seems to be favored by a specific rainfall and temperature range. Furthermore, the amount of brood cells, total number of adults, and nest length were higher in open areas compared to shrubby and secondary vegetations. Therefore, our results show that rainfall, temperature, and vegetation structure are determining factors in C. tarsata nesting in the Brazilian restinga.
\end{abstract}

\section{trap-nests / cavity-nesting bees / pollinators / climate conditions / Malpighiaceae}

\section{INTRODUCTION}

Mutualistic interactions between plants and pollinators play a fundamental role in the maintenance of ecosystem functions and services. Plants provide food resources such as pollen and nectar to pollinators, which in turn help fruit and seed formation through pollination services (Giannini et al. 2015). Bees are the most important and

Corresponding author: D. Costa, danubiamcosta@gmail.com

Manuscript editor: James Nieh effective pollinators. Furthermore, they are ecologically and functionally diverse, forage on a wide variety of floral forms and nest on a myriad of substrates (Klein et al. 2007). The number of bee species worldwide could be as high as 30.000 species (Michener 2007), from which $85 \%$ have a solitary habit (Silva et al. 2001; Buschini and Wolff 2006). Solitary bee species have specific habitat requirements such as pre-existing cavities for nesting as well as flower resources (pollen, nectar, and oil), and thus, they heavily rely on vegetation structure (Ebeling et al. 2012; Flores et al. 2018). Additionally, the reproductive success of solitary bees can be indirectly affected by 
climatic conditions owed to their influence on host plant community richness, composition, physiognomy, and bee nesting biology. Therefore, habitat simplification has adverse effects on bee diversity, which makes preservation efforts pivotal for the maintenance of Aculeata populations (Morato and Campos 2000; Morato and Martins 2006; Faria and Gonçalves 2013; Flores et al. 2018).

Several studies evaluating solitary bee communities in areas with well-defined dry and rainy seasons revealed that Megachile sp. (Megachilidae), Eufriesea nordestina Moure, Euglossa cordata Linnaeus, Tetrapedia diversipes Klug, Xylocopa frontalis Olivier, and species belonging to the genus Centris such as Centris tarsata Smith, C. analis Fabricius, and C. vittata Lepeletier (Apidae) are the most common species (Aguiar and Martins 2002; Aguiar et al. 2005; Mesquita and Augusto 2011; Flores et al. 2018). The genus Centris encloses medium to large-sized solitary bee species, it is predominantly occidental, and distributed from tropical areas of Argentina and Bolivia to the USA (Silveira et al. 2002; Michener 2007). These species need a rich flora to obtain food resources such as nectar, pollen, and floral oils for both larvae and adults. Centris (Hemisiella) tarsata Smith, 1874 is widely distributed in Brazil and it has been recorded in different biomes and climatic conditions countrywide (Silva et al. 2001; Aguiar and Martins 2002; Aguiar and Garófalo 2004; Buschini and Wolff 2006; Mendes and Rêgo 2007; Mesquita and Augusto 2011; Flores et al. 2018).

Although some studies have investigated the vertical nesting of bees in tropical forests (Morato 2001; Mendes and Rêgo 2007; Stangler et al. 2015), they were carried out in the Amazon forest and in semi-deciduous vegetation in Brazil, and in forest remnants in Costa Rica. Information on bee nesting preference for understory or canopy is scarce, and to our knowledge, no study has addressed the vertical nesting behavior of solitary bees in restinga. This tropical and subtropical ecosystem is typical on coastal regions and it is composed by herbaceous plants, shrubs, and arboreous strata on sandy plains under marine influence (Souza et al. 2008; Serra et al. 2016). Accordingly, we addressed the following questions: (1) is there an association among climatic conditions, type of vegetation, and C. tarsata nesting behavior? (2) Do nest architecture (brood cell number built, nest length, cavity width, thickness of entrance and partition walls, and volume of cell) biological characteristics and parasitism vary among vegetation types? (3) Is there preference for $C$. tarsata nesting at different vegetation strata?

\section{MATERIAL AND METHODS}

\subsection{Study area}

The study was carried out in a protected area (763.37 ha) belonging to Empresa Brasileira de Pesquisa Agropecuária (Embrapa) in the municipality of Itaporanga d'Ajuda (11 $06^{\prime} 16.19^{\prime \prime} \mathrm{S} ; 37^{\circ}$ $11^{\prime}$ 05.89" W), in the northeastern Brazilian State of Sergipe. According to Köppen classification, predominant climate in the region is tropical with marked dry (September to February) and rainy (March to August) seasons, with average annual rainfall above $1250 \mathrm{~mm}$. The biome is Atlantic rainforest composed by a matrix of mangrove, restinga, and apicum (sandy open areas influenced by the tidal regime). The study was conducted within the restinga domain. (Nogueira Junior et al. 2013). Rainfall and temperature were respectively obtained from a meteorological station located in the area and from the Instituto Nacional de Meteorologia (INMET) on a per-month basis.

\subsection{Sampling}

Trapnests consisted of 15 pieces of hollow bamboo canes (20.0 cm long) with one node in the middle, forming two internodes (9.0 to $11.0 \mathrm{~cm}$ deep). Bamboo canes had internal diameters ranging from 0.3 to $2.0 \mathrm{~cm}$ evenly distributed ( 5 hollow bamboo canes of 0.3 to $0.8 \mathrm{~cm}, 5$ of 0.9 to $1.4 \mathrm{~cm}$, and 5 of 1.5 to $2.0 \mathrm{~cm}$ of diameter) and they were wrapped together with a $22.0 \mathrm{~cm}$ wide plastic sheet and wire, totaling thirty cavities. Trap-nests were set up in three vegetation types in restinga, viz. (1) open areas-dominance of grasses as Paspalum maritimum Trind., weeds, cactus (Melocactus zehntneri, Britton \& Rose) and some sparsely distributed trees, direct 
sunlight; (2) shrubby vegetations - dominance of shrubs and few tree species as Anacardium occidentale L., Byrsonima crassifolia L. Kunth, Myrciaria tenella (D.C) O. Berg, some grasses, partial shading with high luminosity; and (3) secondary vegetations - dominance of medium to large tree species as A. occidentale, Hancornia speciosa Gomes, Tapira guianensis Aublet, and Inga sp. , dense vegetation, soil covered by a thick litter layer, shaded with low luminosity. Four replicates for each vegetation type were chosen, totaling twelve sampling areas. Study sites were usually clustered in groups of three vegetation types to avoid spatial autocorrelation (Teodoro et al. 2011). At each study site, four trap-nests were hung by a wire and attached to a tree branch at $1.5 \mathrm{~m}$ above the ground and distanced $1.0 \mathrm{~m}$ from each other. Entomological glue was monthly applied to the wire to avoid crawling arthropods. Trap-nests were monthly inspected throughout 2 years (from July 2016 to June 2018) and nested bamboo canes were removed and replaced with empty ones with similar internal diameter.

Nested bamboo canes were individualized in a plastic cage and kept indoors at $27{ }^{\circ} \mathrm{C} \pm 2{ }^{\circ} \mathrm{C}$ until the emergence of $C$. tarsata adults and their cleptoparasites, also known as cuckoo bees or cuckoo wasps that loot brood cells storage (Ebeling et al. 2012) and parasitic flies. Emerging adults were killed, sexed, and the morphometry was performed. Nest architecture features such as the count of brood cells and measures of total nest length (from the first to last cell built), nest width, and thickness of the brood cell partition and entrance wall were also evaluated with a caliper ruler. Brood cell volume was calculated by the formula: $\pi \cdot r^{2} \cdot h$, where $r$ is the width and $h$ is the length of the cell. Wings of three adults of each sex were measured with a scale-magnifier model MG13100, totaling 12 adults (females and males) from each vegetation type, except for secondary vegetation wherein one of the sampling areas, no adults emerged. Identification of nest building material and counting of dead immatures (no emerging individuals of C. tarsata, cleptoparasites, or offspring who died in early stages) were performed 3 months after the nests were taken to the laboratory.

\subsection{Nesting stratification}

An additional nesting stratification preference study was performed by lining up two trap-nests tied together with a wire and attached to a rope at $1.5,3.5$, and $5.5 \mathrm{~m}$ height in open areas and secondary vegetations with four replicates. The rope was attached to a pulley at the tip of a 7.0 m-high bamboo pole. Entomological glue was applied to bamboo pole base to prevent crawling arthropods. Evaluations were monthly conducted for 1 year, beginning in September 2016, and the nested bamboo canes were taken to the laboratory and replaced by empty ones with similar internal diameters. Nested cavities were kept indoors as explained above.

\subsection{Statistical analyses}

Data were nested and analyzed using generalized linear mixed-effects models (GLMEs) with Poisson (discrete variables) or Gaussian (continuous variables) error distributions (Crawley 2007). The models were subjected to analysis of variance (ANOVA), and a posteriori contrasts were performed to assess differences among treatments (Crawley 2007). Spearman correlations were performed between the number of nests built and temperature, rainfall, and tree abundance using ISwR package. Pearson's chi-square test $\left(\chi^{2}\right)$ was performed to compare $C$. tarsata sex ratios among vegetation types. All analyses were performed with $\mathrm{R}$ software version 3.3.1 (R Development Core Team 2016) and subjected to residual analyses in order to assess the suitability of the models and error distributions (Crawley 2007).

A classification and regression tree analysis was further performed for a better understanding of how climatic conditions influenced C. tarsata nest building on different vegetation types. Evaluation period (month), temperature $\left({ }^{\circ} \mathrm{C}\right)$, rainfall $(\mathrm{mm})$, and vegetation types were considered as explanatory variables, while the number of nests built by $C$. tarsata was treated as response variable. The root node represents total sampling, which further divides into two or more sets called decision nodes and into sub-nodes and/or terminal nodes. Differences among sub-nodes and parent 
node were accessed through the chi-squared automatic interact detection (CHAID) method (Kass 1980). The analysis was performed in XLSTAT 2014.5.3 and adjusted by Bonferroni correction, at $5 \%$ significance level.

\section{RESULTS}

\subsection{Centris tarsata nesting according to vegetation type}

A total of 162 nests of $C$. tarsata were collected, the majority in open areas $(52.47 \%), 37.03 \%$ in shrubby, and only $10.50 \%$ in secondary vegetations. Altogether, 585 adults of C. tarsata emerged from the nests, most of them from open areas $(59.6 \%)$, followed by $32.14 \%$ from shrubby vegetations, and $8.20 \%$ from secondary vegetations. The cuckoo bee Mesocheira bicolor Fabricius $(54.05 \%)$ was the main C. tarsata natural enemy emerging from nests, followed by an Anthidiini species (37.84\%) and Coelioxys sp. (1.8\%) (Megachilidae). Other natural enemies emerging from nests were the dipterans Anthrax sp1 $(4.5 \%)$ and Anthrax sp2 (1.8\%) (Bombyliidae).

Centris tarsata nesting period lasted from October 2016 to February 2017, peaking in November and December during the dry season. A new nesting cycle was recorded from September 2017 until January 2018, peaking in November and in January (Figure 1). Nesting was negatively correlated with rainfall ( $r h o=-0.581, P<0.01)$ and abundance of tree species ( $r h o=-0.755$, $P<0.01$ ), but not with temperature (rho = $0.2047, P>0.05)$.

Classification and regression tree analysis yielded five levels of depth as shown in Figure 2. In higher temperatures, the mean number of nests was 0.81 in $36 \%$ of samples $(P<0.001)$ contrasting with a lower number $(0.28)$ in $64 \%$ of samples in lower temperatures $(P<0.05)$. In shrubby and secondary vegetations, nesting mostly occurred when temperatures were high and associated to a low rainfall $(P<0.001)$. Also, there was no nesting in $16 \%$ of samples in shrubby and secondary vegetations with increasing rainfall $(P<$ $0.001)$. In open areas, the main explanatory factor was the sampling period, being the mean number of nests $(1.25)$ higher in December in $1.3 \%$ of samples $(P<0.001)$ followed by September and October. Moreover, the mean number of nests was higher $(4.0)$ in $1.3 \%$ of samples $(P<0.001)$ when the temperature increased in June, July, August, and November. In those months, there was a decrease in cumulative rainfall in relation to the previous period (Figure 1).

\subsection{Nest architecture and bionomical characteristics}

Nests were constructed with a mixture of sand and vegetal oil which covered the outer wall of the entrance, hardening after drying. Brood cells were arranged according to cavity width, linear in smaller sized cavities, perpendicular in medium sized, and in some cases, overlapping each other in larger cavities. The inner brood cell was smooth and hard in appearance, covered by a cellophane-like film. Brood cells contained a dark yellow to brown mixture of pollen and nectar as food supply for larvae.

The number of brood cells built per nest differed among vegetation types: open areas had the highest numbers, followed by shrubby and secondary vegetations. There was no difference in nest width, wall thickness, and brood cell volume among vegetation types. The partition wall thickness of the brood cells was higher in secondary vegetations compared to open areas and shrubby vegetations (Table I).

After field collection, emergence of adults from nests ranged from 2 to 49 days for males and from 4 to 40 days for females. The total number of emerged adults and males of $C$. tarsata was influenced by vegetation types $\left(\chi^{2}=4.84\right.$, d.f. $=1, P<$ $0.001 ; \chi^{2}=7.75$, d.f. $=1, P<0.01$, respectively), being highest in shrubby vegetations, followed by open areas and secondary vegetations. The mean number of females, cleptoparasites, and dead immatures were also influenced by vegetation types $\left(\chi^{2}=15.67\right.$, d.f. $=1, P<0.001 ; \chi^{2}=6.62$, d.f. $=1$, $P<0.01 ; \chi^{2}=31.67$, d.f. $=1, P<0.01$, respectively), with higher values for open areas, followed by shrubby and secondary vegetations. There was no difference in the size of males or females wings $\left(\chi^{2}=0.48\right.$, d.f. $=2, P>0.05 ; \chi^{2}=0.08$, d.f. $=2$, $P>0.05$, respectively) (Table I) among vegetation types. Sex ratio was significantly male biased in 


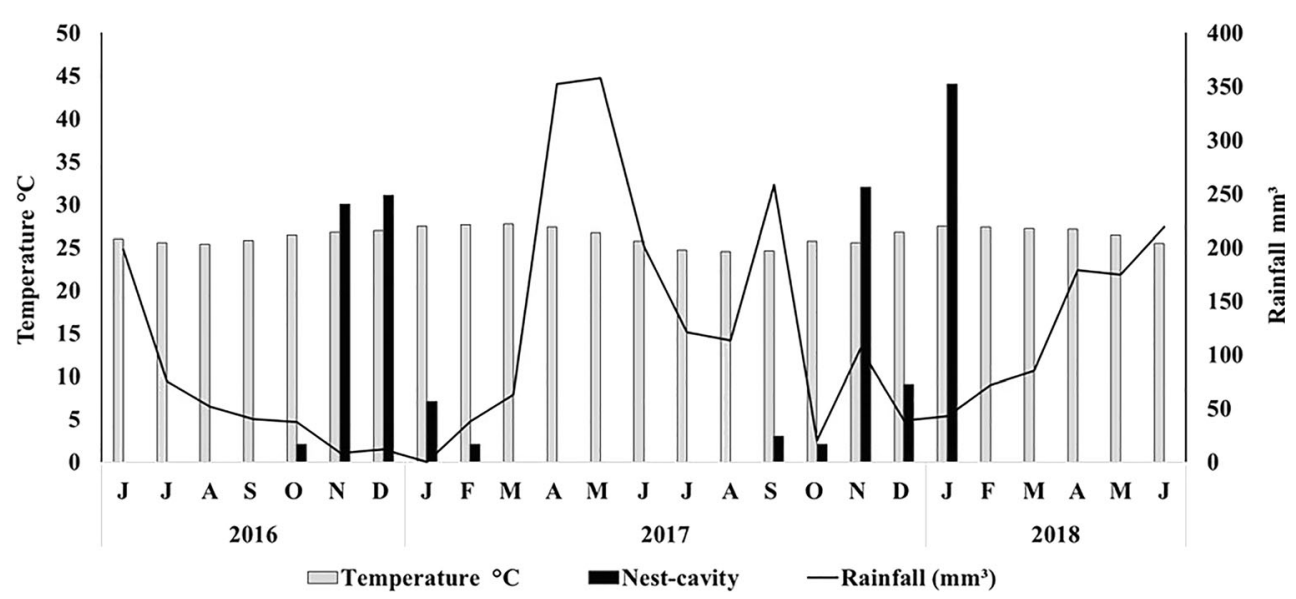

Figure 1. Temperature $\left({ }^{\circ} \mathrm{C}\right)$, rainfall $(\mathrm{mm})$, and number of nests built by $C$. tarsata in restinga open areas, shrubby, and secondary vegetations from July 2016 to June 2018.

secondary vegetations $\left(\mathrm{sr}=1: 0.37, \chi^{2}=13.13\right.$, d.f. $=5, P<0.05)$, but not in open areas $(\mathrm{sr}=$ $1: 0.35, \chi^{2}=19.33$, d.f. $\left.=19, P>0.05\right)$ and shrubby vegetations $\left(\mathrm{sr}=1: 0.27, \chi^{2}=17.42\right.$, d.f. $=13$, $P>0.05)$.

\subsection{Nesting stratification}

A total of 31 nests founded by $C$. tarsata were collected, roughly half of which (14 nests) in open areas and closer to the soil (1.5 m height), followed by 9 and 3 nests at $3.5 \mathrm{~m}$ and $5.5 \mathrm{~m}$ height, respectively. We observed considerable fewer nests in secondary vegetations $(16.13 \%$; 1 nest at $1.5 \mathrm{~m}$ and 2 nests at $3.5 \mathrm{~m}$ and $5.5 \mathrm{~m}$ height). The cuckoo bee $M$. bicolor was the only cleptoparasite that emerged from the nests and it was found only in open areas.

The highest number of brood cells and dead immatures $(P<0.001)$ was recorded at $1.5 \mathrm{~m}$ height and the lowest at $5.5 \mathrm{~m}$ in open areas. The total of individuals was lower in nests closer to the canopy (at $5.5 \mathrm{~m}$ height) when compared to those nearer to the soil (1.5 m height). Neither vegetation nor trapnest height influenced the total number of males and females (Table II).

\section{DISCUSSION}

Rainfall was the main climate condition explaining $C$. tarsata nesting patterns over the 2-year sampling period, and it was negatively correlated with nesting. In contrast, temperature had no influence on nesting, possibly owing to its low variation throughout the year, which contrasts with well-defined rainy and drought periods in the study region. However, when temperature and rainfall were analyzed in relation to the type of vegetation and throughout the sampling period, new results emerged. The classification and regression tree shows two distinct groups of C. tarsata (Figure 2): one influenced directly by rainfall and temperature and another influenced by the sampling period. Nesting in shrubby and secondary vegetations was favored at low rainfall and high temperature, increasing rainfall ceases nesting, possibly because high humidity is unfavorable for nesting. In open areas, C. tarsata nesting was also generally concentrated during the dry season, in months of low rainfall and higher temperatures. Either drought or rainfall periods beyond normal may disturb floral resources availability and consequently, bee frequency. The frequent annual population fluctuations appear to be a regular feature for bee species that nest in pre-existing cavities (Frankie et al. 1998).

This nesting pattern in the dry season is consistent with results from other Brazilian vegetations such as eucalyptus, riparian, and mesophytic forests in Maranhão State, semi-deciduous seasonal forest and open savanna in Paraíba State, 


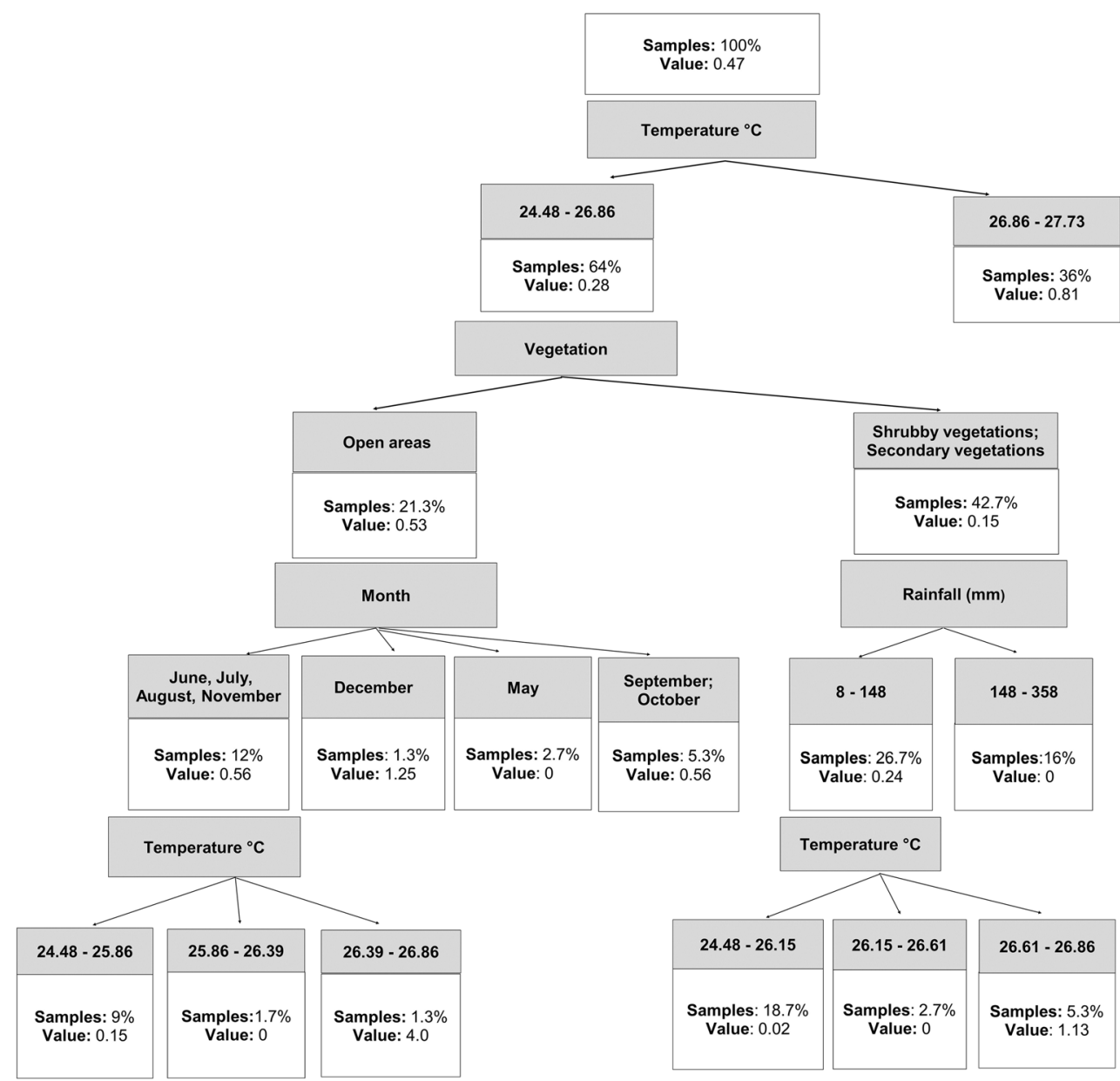

Figure 2. Regression tree showing the influence of climatic conditions and sampling period on nesting by C. tarsata in restinga open areas, shrubby, and secondary vegetations.

and swamps and pastures in the southern region (Aguiar and Martins 2002; Buschini and Wolff 2006; Mendes and Rêgo 2007). However, Aguiar and Garófalo (2004) observed more C. tarsata nests during the rainy season in semideciduous and semiarid caatinga vegetations. Sunny habitats can provide more resources for the construction and provision of nests, such as floral resources, when compared to shaded habitats, as observed in open areas. Concerning floral resources, we frequently observed $C$. tarsata foraging on Byrsonima crassifolia (Malpighiaceae) mainly in shrubby vegetations, which is in line with other studies that recorded bees foraging for oil and pollen on Byrsonima spp. (Mendes and Rêgo 2007; Mello et al. 2013).
Our results show that $C$. tarsata, in restinga vegetation, acts as a bivoltine species with two generations per year, each generation lasting approximately 2 months. Nests were found for only 5 months per year, in both years. Similar results were found by Buschini and Wolff (2006) for C. tarsata and by Martins et al. (2014) for C. flavifrons . Aguiar and Garófalo (2004) studying $C$. tarsata nesting behavior in caatinga and semi-deciduous vegetation observed some nests diapausing after being established in mid-rainy season (caatinga vegetation) or in mid-dry season (semi-deciduous vegetation), both stressful periods. These authors suggested that $C$. tarsata possibly spends stressful periods either as adults or as prepupae in diapause to withstand harsh 
Table I. Nest architecture and bionomical characteristics of $C$. tarsata individuals in relation to restinga vegetation types

\begin{tabular}{|c|c|c|c|c|c|c|c|c|c|}
\hline & \multicolumn{2}{|c|}{ Open areas } & \multicolumn{2}{|c|}{ Shrubby vegetations } & \multicolumn{2}{|c|}{$\begin{array}{l}\text { Secondary } \\
\text { vegetations }\end{array}$} & \multirow[b]{2}{*}{$x^{2}$} & \multirow[b]{2}{*}{ d.f. } & \multirow[b]{2}{*}{$P$} \\
\hline & $X \pm \mathrm{SD}$ & $N$ & $X \pm \mathrm{SD}$ & $N$ & $X \pm \mathrm{SD}$ & $N$ & & & \\
\hline Total brood cells & $12.87 \pm 23.96$ & 515 & $7.32 \pm 12.73$ & 293 & $2.30 \pm 4.45$ & 92 & 214.6 & 1 & $<0.001$ \\
\hline Nest length $(\mathrm{cm})$ & $5.95 \pm 1.33$ & 85 & $5.43 \pm 1.54$ & 60 & $4.48 \pm 1.05$ & 17 & 6.69 & 1 & $<0.05$ \\
\hline Cavity width (cm) & $1.45 \pm 1.59$ & 85 & $1.66 \pm 2.30$ & 60 & $1.07 \pm 0.27$ & 17 & 0.61 & 2 & $>0.05$ \\
\hline $\begin{array}{l}\text { Thickness of } \\
\text { partition walls } \\
(\mathrm{mm})\end{array}$ & $0.77 \pm 0.004$ & 85 & $0.78 \pm 0.01$ & 60 & $0.79 \pm 0.017$ & 17 & 5.66 & 1 & $<0.05$ \\
\hline $\begin{array}{l}\text { Thickness of the } \\
\text { entrance walls } \\
(\mathrm{mm})\end{array}$ & $0.82 \pm 0.063$ & 85 & $0.79 \pm 0.026$ & 60 & $0.82 \pm 0.024$ & 17 & 0.11 & 2 & $>0.05$ \\
\hline $\begin{array}{l}\text { Volume of cells } \\
\left(\mathrm{cm}^{3}\right)\end{array}$ & $2.06 \pm 0.56$ & 85 & $1.89 \pm 0.43$ & 60 & $2.06 \pm 0.70$ & 17 & 0.43 & 2 & $>0.05$ \\
\hline Total of individuals & $13.04 \pm 16.46$ & 349 & $14.35 \pm 19.13$ & 188 & $3.31 \pm 5.10$ & 48 & 4.84 & 1 & $<0.001$ \\
\hline Total of males & $8.27 \pm 11.18$ & 224 & $9.47 \pm 11.58$ & 138 & $2.31 \pm 3.56$ & 30 & 7.75 & 1 & $<0.01$ \\
\hline Total of females & $4.77 \pm 6.17$ & 125 & $4.11 \pm 5.36$ & 50 & $1.5 \pm 2.15$ & 18 & 15.67 & 1 & $<0.001$ \\
\hline $\begin{array}{l}\text { Total of } \\
\text { Cleptoparasites }\end{array}$ & $1.32 \pm 2.64$ & 52 & $1.92 \pm 3.99$ & 29 & $0.22 \pm 0.61$ & 5 & 6.62 & 1 & $<0.01$ \\
\hline $\begin{array}{l}\text { Total of dead } \\
\text { immatures }\end{array}$ & $2.82 \pm 7.0$ & 114 & $1.9 \pm 3.87$ & 76 & $0.95 \pm 2.09$ & 39 & 31.67 & 1 & $<0.001$ \\
\hline $\begin{array}{l}\text { Male wing length } \\
(\mathrm{mm})\end{array}$ & $9.71 \pm 0.75$ & 12 & $9.61 \pm 0.72$ & 12 & $9.83 \pm 0.86$ & 9 & 0.48 & 2 & $>0.05$ \\
\hline $\begin{array}{l}\text { Female wing length } \\
(\mathrm{mm})\end{array}$ & $9.94 \pm 0.53$ & 12 & $9.94 \pm 0.60$ & 12 & $10.0 \pm 0.68$ & 8 & 0.08 & 2 & $>0.05$ \\
\hline
\end{tabular}

$N=$ total number, $X \pm \mathrm{SD}=$ mean \pm standard deviation

environmental conditions. In fact, evidence indicates that diapause is the primary mechanism through which the annual rhythm of insect lifehistory phases are appropriately synchronized to seasonal conditions and it is subjected to both genetic and environmental influence (Tauber and Tauber 1981; Faria and Gonçalves 2013). Another strategy may be taking shelter in unknown places, as suggested by Pereira et al. (1999) and Ramos et al. (2010). Adults of $C$. tarsata might diapause in restinga vegetation during stressful periods, but this remains yet to be investigated.

Regarding nest architecture, $C$. tarsata females built thicker brood cells partition wall in secondary vegetations compared to open areas and shrubby vegetations. This could be related to the smaller amount of resources for nest building (sand) in secondary vegetations, since its ground is covered by a large amount of litter. However, vegetation type did not influence the thickness of entrance plug wall and we observed a layer of oil outside of all nests entrance plug, which may be a characteristic from subgenus Hemisiella to protect the nest (Pereira et al. 1999; Buschini and Wolff 2006).

Sex ratio was male biased in secondary vegetation, but not in open areas and shrubby vegetations. Aguiar and Martins (2002) and Aguiar and Garófalo (2004) also reported a male-biased sex ratio for $C$. tarsata. However, Silva et al. (2001), Buschini and Wolff (2006) and Mendes and Rêgo (2007) found a femalebiased sex ratio. According to Silva et al. (2001), sex ratio is often variable and it is associated to the abundance of resources available in the environment for females. Also, a lower number of emerging females might be caused by parasitism, as parasites and cleptoparasites prefer female brood 
Table II. Influence of vegetation and height on nesting features by C. tarsata in restinga open areas, shrubby, and secondary vegetations

\begin{tabular}{llccc}
\hline Response variable & Explanatory variable & $\chi^{2}$ & d.f. & $P$ \\
\hline Brood cells & Vegetation & 34.503 & 1 & $<0.001$ \\
& Height & 66.109 & 2 & $<0.05$ \\
Vegetation $\times$ height & 87.237 & 2 & $<0.001$ \\
Dead immatures & Vegetation & 46.145 & 1 & $<0.05$ \\
& Height & 36.669 & 2 & $<0.001$ \\
& Vegetation $\times$ height & 82.519 & 2 & $<0.05$ \\
Total individuals & Vegetation & 0.191 & 1 & $>0.05$ \\
& Height & 42.019 & 2 & $>0.05$ \\
& Vegetation $\times$ height & 6.224 & 2 & $<0.05$ \\
Total males & Vegetation & 0.411 & 1 & $>0.05$ \\
& Height & 2.598 & 1 & $>0.05$ \\
Total females & Vegetation $\times$ height & 0.2507 & 2 & $>0.05$ \\
& Vegetation & 1.901 & 1 & $>0.05$ \\
& Height & 1.626 & 1 & $>0.05$ \\
& Vegetation $\times$ height & 2.313 & 2 & $>0.05$ \\
\hline
\end{tabular}

cells, possibly due to higher nutritional quality of food stored (Aguiar and Martins 2002; Buschini and Wolff 2006).

Cleptoparasites observed in C. tarsata nests were the cuckoo bees M. bicolor, Coelioxys sp. and Anthidiini, and the dipterans Anthrax sp1, Anthrax sp2, which were also recorded in other Brazilian biomes (Aguiar and Martins 2002; Aguiar and Garófalo 2004; Buschini and Wolff 2006). According to a study carried out in small secondary forest remnants in Costa Rica, parasitism rates tend to be high in the understory due to the dominance of Centris, which was observed nesting at a $2.0-\mathrm{m}$ height (Stangler et al. 2015). Here, the low parasitism rate recorded in the understory may possibly be due to the low number of nests founded. Therefore, further studies are needed to elucidate the parasitism of $C$. tarsata in restinga, mainly in the understory and canopy.

The number of dead immatures was higher in open areas, possibly due to a related high number of nests and brood cells built. Moreover, climate conditions, especially temperature, can reach extreme values in open areas, potentially increasing larvae and juvenile bee mortalities (Jesus and
Garófalo 2000; Aguiar and Garófalo 2004; Buschini and Wolff 2006).

In open areas, $C$. tarsata preferred to nest in trapnests near the ground unlike in secondary vegetations, where only one nest was built at this height. This preference for lower heights in restinga may be favored by proximity from nestbuilding resources such as sand, and floral source such as oil, nectar, and pollen. On the other hand, for denser habitats such as secondary forests, microclimatic conditions may be more favorable for nesting at higher strata, which may explain our results for secondary vegetation. Also, Mendes and Rêgo (2007) observed that C. tarsata built more nests in the canopy of eucalyptus (5 to $12 \mathrm{~m}$ height) and mesophytic forest (12.0 m height) compared to nests at $1.5 \mathrm{~m}$ height.

In restinga, rainfall is a determining factor in C. tarsata nesting which was concentrated in the dry season, mainly in open areas, where we also recorded the greatest amount of brood cells and highest nest length. In shrubby and secondary vegetations, nesting seems to be favored by specific climatic conditions present in the understory and canopies especially in the harsh dry season. Centris tarsata preferred 
to nest in the understory in secondary vegetations and open areas, however, further studies on nesting behavior and exploitation of floral resources in restinga are needed in order to improve the management and maintenance of related ecosystem functions and services.

\section{ACKNOWLEDGMENTS}

We are thankful to Dr. Felipe Vivallo from Museu Nacional do Rio de Janeiro for the collaboration in the identification of $C$. tarsata. We also thank both reviewers for helpful comments and suggestions, and to the Coordenação de Aperfeiçoamento de Pessoal (CAPES) for granting the scholarship for the first author and to Embrapa Tabuleiros Costeiros for permission to assess the study area and for providing logistical support.

\section{AUTHORS' CONTRIBUTIONS}

DMC and AVT conceived this research and designed experiments; MCB participated in the design, analysis, and interpretation of the data; ASB participated in the design; IB performed analysis and interpretation of the data. All authors read and approved the final manuscript.

\section{COMPLIANCE WITH ETHICAL STANDARDS}

Conflict of interest The authors declare that they have no conflict of interest.

Les précipitations, la température et le type de végétation influencent la nidification de l'abeille récolteuse d'huile Centris (Hemisiella) tarsata dans le biome de la Restinga Brésilienne

Nids pièges / abeilles nichant dans les cavités / pollinisateurs / conditions climatiques / Malpighiaceae

Regenmenge, Temperatur und Vegetationstyp beeinflussen das Nistverhalten der ölsammelnden Biene Centris (Hemisiella) tarsata im brasilianischen Restinga Biom

Nistfallen / höhlennistende Bienen / Bestäuber / Klimabedingungen / Malpighiaceae

\section{REFERENCES}

Aguiar, C. M. L.; Garófalo, C. A. (2004). Nesting biology of Centris (Hemisiella) tarsata Smith (Hymenoptera, Apidae, Centridini). Rev. Bras. Zool. 21 (3), 477-486. https://doi.org/10.1590/s0101-81752004000300009

Aguiar, A. J. C.; Martins, C. F. (2002). Abelhas e vespas solitárias em ninhos-armadilha na Reserva Biológica Guaribas (Mamanguape, Paraíba, Brasil). Rev. Bras. Zool. 19 (1), 101-116. https://doi.org/10.1590/s010181752002000500005

Aguiar, C. M. L.; Garófalo, C. A.; Almeida, G. F. (2005). Trap-nesting bees (Hymenoptera, Apoidea) in areas of dry semideciduous forest and caatinga, Bahia, Brazil. Rev. Braz. Zool. 22 (4), 1030-1038. https://doi. org/10.1590/S0101-81752005000400031

Buschini, M. L. T.; Wolff, L. L. (2006). Nesting biology of Centris (Hemisiella) tarsata Smith in southern Brazil (Hymenoptera, Apidae, Centridini). Braz. J. Biol. 66 (4), 1091-1101. https://doi.org/10.1590/s151969842006000600016

Crawley, M.J. (2007). The R book. John Wiley \& Sons Ltd, Wests Sussex.

Ebeling, A.; Klein, A.M.; Weisser, W.W.; Tscharntke, T. (2012). Multitrophic effects of experimental changes in plant diversity on cavity-nesting bees, wasps, and their parasitoids. Oecologia. 169 (2), 453-465. https://doi.org/10.1007/s00442-011-2205-8

Faria, L. R. R; Gonçalves, R. B. (2013) Abiotic correlates of the bee diversity and composition along eastern Neotropics. Apidologie. 44 (5), 547-562. https://doi. org/10.1007/s13592-013-0205-X

Flores, L. M. A.; Zanette, L. R. S.; Araújo, F. S. (2018). Effects of habitat simplification on assemblages of cavity nesting bees and wasps in a semiarid neotropical conservation area. Biodivers. Conserv. 27 (2), 311328. https://doi.org/10.1007/s10531-017-1436-3

Frankie, G. W., Vinson, S. B., Rizzardi, M. A., Griswold, T. L., O'Keefe, S., Snelling, R.R. (1998). Diversity and abundance of bees visiting a mass flowering tree species in disturbed seasonal dry forest, Costa Rica. J. Kansas Entomol. Soc. 70 (4), 281-296.

Giannini, T. C.; Boff, S.; Cordeiro, G.D.; Cartolano Jr., E. A.; Veiga, A. K.; Imperatriz-Fonseca, V. L.; Saraiva, A. M. (2015). Crop pollinators in Brazil: a review of reported interactions. Apidologie. 46 (2), 209-223. https://doi.org/10.1007/s13592-014-0316-Z

Jesus, B. M. V., Garófalo, C. A. (2000). Nesting behaviour of Centris (Heterocentris) analis (Fabricius) in southeastern Brazil (Hymenoptera, Apidae, Centridini). Apidologie, 31 (4), 503-515. https://doi.org/10.1051 /apido:2000142

Kass, G. V. (1980). An exploratory technique for investigating large quantities of categorical data. Appl. Stat., 29 (2), 119-127

Klein, A. M., Vaissière, B. E., Cane, J. H., SteffanDewenter, I., Cunningham, S. A., Kremen, C., Tscharntke, T. (2007). Importance of pollinators in 
changing landscapes for world crops. Proc. R. Soc. B 274 (1608), 303-313. https://doi.org/10.1098 /rspb.2006.3721

Martins, C. F.; Peixoto, M. P; Aguiar, C. M. L. (2014) Plastic nesting behaviour of Centris (Centris) flavifrons (Hymenoptera: Apidae: Centridini) in an urban area. Apidologie. 45 (2), 156-171. https://doi. org/10.1007/s13592-013-0235-4

Mello, M. A. R., Bezerra, E. L. S., Machado, I. C. (2013). Functional roles of Centridini oil bees and Malpighiaceae oil flowers in biome-wide pollination networks. Biotropica. 45 (1), 45-53. https://doi. org/10.1111/j.1744-7429.2012.00899.x

Mendes, F. N.; Rêgo, M. M. C. (2007). Nidificação de Centris (Hemisiella) tarsata Smith (Hymenoptera, Apidae, Centridini) em ninhos-armadilha no Nordeste do Maranhão. Brasil. Rev. Bras. Entomol. 51 (3), 382388 . https://doi.org/10.1590/s008556262007000300017

Mesquita, T. M. S., Augusto, S. C. (2011). Diversity of trap-nest bees and their natural enemies in the Brazilian savanna. Trop. Zool. 24 (2), 127-144

Michener, C. D. (2007). The bees of the world. The Johns Hopkins University Press, Baltimore.

Morato, E. F. (2001). Efeitos da fragmentação florestal sobre vespas e abelhas solitárias na Amazônia Central. II. Estratificação vertical. Rev. Bras. Zool. 18 (3), 737747. https://doi.org/10.1590/s0101-81752001000300010

Morato E.F.; Campos, L.A.O. (2000). Efeitos da fragmentação florestal sobre vespas e abelhas solitárias na Amazônia Central. Rev. Bras. Zool. 17 (2), 429-444. https://doi. org/10.1590/s0101-81752000000200014

Morato, E. F.; Martins, R. P. (2006). An overview of proximate factors affecting the nesting behavior of solitary wasps and bees (Hymenoptera: Aculeata) in preexisting cavities in wood. Neotrop. Entomol. 35 (3), 285-298. https://doi.org/10.1590/s1519-566 x2006000300001

Nogueira Junior, L. R.; Dompieri, M. H. G.; Rangel, M. S. A. Rodrigues, R. F. A.; Melo, A. F. R. et al. (2013). Plano de Manejo Reserva Particular do Patrimônio Natural do Caju. Embrapa Tabuleiro Costeiros. Aracaju.

Pereira, M.; Garófalo, C. A.; Camillo, E.; Serrano, J. C. (1999). Nesting biology of Centris (Hemisiella) vittata Lepeletier in southeastern Brazil (Hymenoptera, Apidae, Centridini). Apidologie. 30, 327-338. https://doi.org/10.1051/apido:19990409
R Core Team (2016). R: A language and environment for statistical computing. R Foundation for Statistical Computing, Vienna. https://www.R-project.org/.

Ramos, M.; Albuquerque, P.; Rêgo, M. (2010). Nesting behaviour of Centris (Hemisiella) vittata Lepeletier (Hymenoptera: Apidae) in an area of the cerrado in the northeast of the State of Maranhão, Brazil. Neotrop. Entomol. 39 (3), 379-383. https://doi.org/10.1590 /s1519-566x2010000300011

Serra, F. C. V.; Lima, P. B.; De Almeida E. B. Jr, (2016). Species richness in restinga vegetation on the eastern Maranhão State, Northeastern Brazil. Acta Amaz 46 (3), 271-280. https://doi.org/10.1590/18094392201504704

Silva, F. O.; Viana, B. F.; Neves, E. L. (2001). Biologia e arquitetura de ninhos de Centris (Hemisiella) tarsata Smith (Hymenoptera: Apidae: Centridini). Neotrop. Entomol. 30 (4), 541-545. https://doi.org/10.1590 /s1519-566x2001000400005

Silveira, F. A.; Melo, G. A. R.; Almeida, E. A. B. (2002). Abelhas brasileiras: sistemática e identificação. Fund. Araucária, Belo Horizonte.

Souza, C. R. G., Hiruma, S. T., Sallun, A. E. M., Ribeiro, R. R., Sobrinho, J. M. A. (2008). "Restinga" conceitos e empregos do termo no Brasil e implicações na legislação ambiental. Instituto Geológico, São Paulo.

Stangler, E. S.; Hanson, P. E.; Steffan-Dewenter, I. (2015). Vertical diversity patterns and biotic interactions of trap-nesting bees along a fragmentation gradient of small secondary rainforest remnants. Apidologie. 47 (4), 527-538. https://doi.org/10.1007/s13592-015$0397-3$

Tauber, C. A.; Tauber, M. J. (1981). Insect seasonal cycles: genetics and evolution. Annu. Rev. Ecol. Syst. 12 (1), 281-308. https://doi.org/10.1146/annurev. es.12.110181.001433

Teodoro, A. V., Muñoz, A., Tscharntke, T., Klein, A. M., Tylianakis, J. (2011). Early succession arthropod community changes on experimental passion fruit plant patches along a land-use gradient in Equador. Agric. Ecosyst. Environ. 140 , 14-19. https://doi.org/10.1016 /j.agee.2010.11.006

XLSTAT (2014). Data analysis and statistical solution for Microsoft Excel. Addinsoft, Paris, France.

Publisher's note Springer Nature remains neutral with regard to jurisdictional claims in published maps and institutional affiliations. 